\title{
SEASONAL VARIATION OF HEAVY METAL POLLUTION OF GROUNDWATER AND SOIL IN THE M'NASRA REGION (GHARB, MOROCCO)
}

\section{Serine OMRANIA ${ }^{* 1}$, Najib EL KHODRANI ${ }^{2}$, Mbark LAHMAR ${ }^{1,2}$, Ahmed DOUAIK ${ }^{2}$, Hamza IAAICH $^{2}$, Souad EL HAJJAJI ${ }^{1}$, Abdelmjid ZOUAHRI ${ }^{2}$}

${ }^{1}$ Laboratory of Spectroscopy, Molecular Modeling, Materials, Nanomaterials, Waters and Environment, CERNE2D, Faculty of Sciences, Mohammed V University, Rabat, Morocco

${ }^{2}$ Research Unit on Environment and Conservation of Natural Resources, Regional Center of Rabat, National Institute of Agricultural Research (INRA), Rabat, Morocco

Received - September 20, 2021; Revision - December 03, 2021; Accepted - December 12, 2021

Available Online - December 30, 2021

DOI: http://dx.doi.org/10.18006/2021.9(6).813.822

\section{KEYWORDS}

Groundwater

Heavy Metal

Hierarchical cluster analysis

Nemerow index

Soil

Vertical transfer

\begin{abstract}
M'nasra region is well known for increasing levels of heavy metal pollution in the environment, mainly due to waste discharge of Ouled Berjal, the irrational use of fertilizers, and the discharge of waste from several industries. The objective of this study was to access the seasonal variations in the groundwater and soil quality with respect to heavy metal pollution. Water samples from wells and samples from soil near them were taken during wet (January - March 2017) and dry (July 2017) seasons and concentrations of Cd, Cu, Cr, Mn, Ni, Pb, and $\mathrm{Zn}$ were determined using an Atomic Absorption Spectrophotometer (AAS). Contamination factor for each heavy metal and Nemerow pollution index was calculated. Results of the study revealed a decrease in pollution degree from wet to dry for soil and an increase in the case of groundwater. $\mathrm{Cu}$ had the lowest and $\mathrm{Ni}$ had the highest concentration in irrigation water whereas, for soil, $\mathrm{Cd}$ had the lowest and $\mathrm{Zn}$ had the highest concentration. During the wet season, all the concentrations of heavy metals decreased compared to the dry season, this can be explained by the dilution of these concentrations by precipitation water and therefore to lower absorption of these heavy metals in the water of irrigations and/or soil. Vertical transfer of pollutants from topsoil to groundwater was assessed using Hierarchical Cluster Analysis to identify associations between heavy metals and soil texture. In the case of $\mathrm{Ni}$ and $\mathrm{Cr}$, the variables corresponding to the concentrations from soil and groundwater were part of the same cluster, in both seasons, the distribution maps of concentrations confirmed the pattern of transfer. This study can be considered as a baseline for the seasonal variation of heavy metal pollution of groundwater and soil. This study can be used not only for monitoring the study area but also as a tool for the implementation of environmental protection policies.
\end{abstract}

* Corresponding author

E-mail: serineomrania@gmail.com (Serine OMRANIA)

Peer review under responsibility of Journal of Experimental Biology and Agricultural Sciences.

Production and Hosting by Horizon Publisher India [HPI] (http://www.horizonpublisherindia.in/).

All rights reserved.
All the articles published by Journal of Experimental Biology and Agricultural Sciences are licensed under a Creative Commons Attribution-NonCommercial 4.0 International License Based on a work at www.jebas.org.

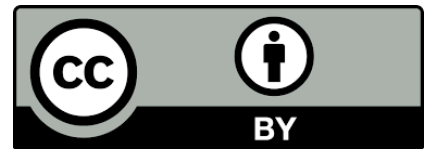




\section{Introduction}

To provide clean and potable water for human and agricultural purposes in order to prevent environmental and human health risks is one of the greatest challenges of Agenda 2030 for Sustainable Development. This includes aspects of water quality (degree of contamination), accessibility ("located on-premises"), and availability ("available when needed") to further address the normative criteria of the human right to water (WHO/UNICEF, 2017; UN-Water SDG 6 Synthesis Report, 2018). In developing countries, heavy metal contamination of farmland is occurring, which is a severe environmental problem due to the toxicity of heavy metals (Agca \& Özdel, 2014). In recent decades, the concentrations of heavy metals and metalloids in irrigation water, and soil, have been greatly increasing on farmland due to anthropogenic activities including the expansion of industrialization and urbanization (Islam et al., 2017). Increased heavy metal concentrations are particularly harmful because heavy metals are toxic, persistent, and non-biodegradable (Yan et al., 2018). Cadmium (Cd) is toxic to humans because it can mimic the metabolic functions of zinc (an essential element), thus modifying the activity of enzymes in the body. Cd exposure may cause kidney problems and deterioration of bones and prolonged exposures (occupational) can cause lung, stomach, or prostate cancer (Navarro Silvera \& Rohan, 2007; Jarup \& Akesson, 2009). Lead $(\mathrm{Pb})$ can mimic the metabolic functions of calcium $(\mathrm{Ca})$ and inhibits the activity of most enzymes. Also, it can affect the functioning of the intestinal tract and can cause anemia and renal dysfunction. In the case of children, even in small amounts, it may cause adverse effects on the central nervous system as well as on the renal function (Hellström et al., 2004). Copper $(\mathrm{Cu})$, Manganese (Mn), and Zinc ( $\mathrm{Zn})$ are essential elements for all living organisms, but excess of these have adverse effects on human health (Aaseth \& Norseth,1986; De Bie et al., 2005). Intensive agriculture is mainly based on the excessive use of agrochemicals which favors the enrichment of agricultural soil with heavy metals as $\mathrm{Cd}, \mathrm{Cu}, \mathrm{Pb}, \mathrm{Ni}$, and $\mathrm{Zn}$ from manure, pesticides, and fertilizers (Wuana \& Okieimen, 2011). Heavy metals do not undergo microbial or chemical degradation due to their characteristics, the soil is acting as a sink, the transfer of heavy metals in case of agricultural soils being mostly through plant uptake, air transfer, or vertical transfer during rainfall (Rajmohan et al., 2014), to deeper layers of soil and groundwater.

Many studies have been conducted on the seasonal variation of heavy metal pollution in water and soil in different parts of the world (Ben Salem et al., 2014; Banerjee et al., 2016; Sophia et al., 2019; Nyantakyi et al., 2019; Minhaz et al., 2019). However, in Morocco, very little work has been done regarding seasonal variation in heavy metals pollution in water and soil. Nshimiyimana et al. (2014) have been carried out a similar study in Aarjaat village, Morocco.

In the M'nasra zone, Morocco, groundwater is used by the population without any treatment for both drinking and irrigation purposes, while the use of chemical products in agriculture is a common practice for most farmers. Also, in the same study zone, we noticed the irrational use of pesticides and fertilizers by farmers. At the same time, contamination with heavy metals has never been assessed in the zone.

The objective of this current research was to assess the concentrations of heavy metals from the groundwater and agricultural soil of the M'nasra zone, Morocco, to identify their seasonal variation and to identify locations where the risk of contamination is manifesting and to which extent.

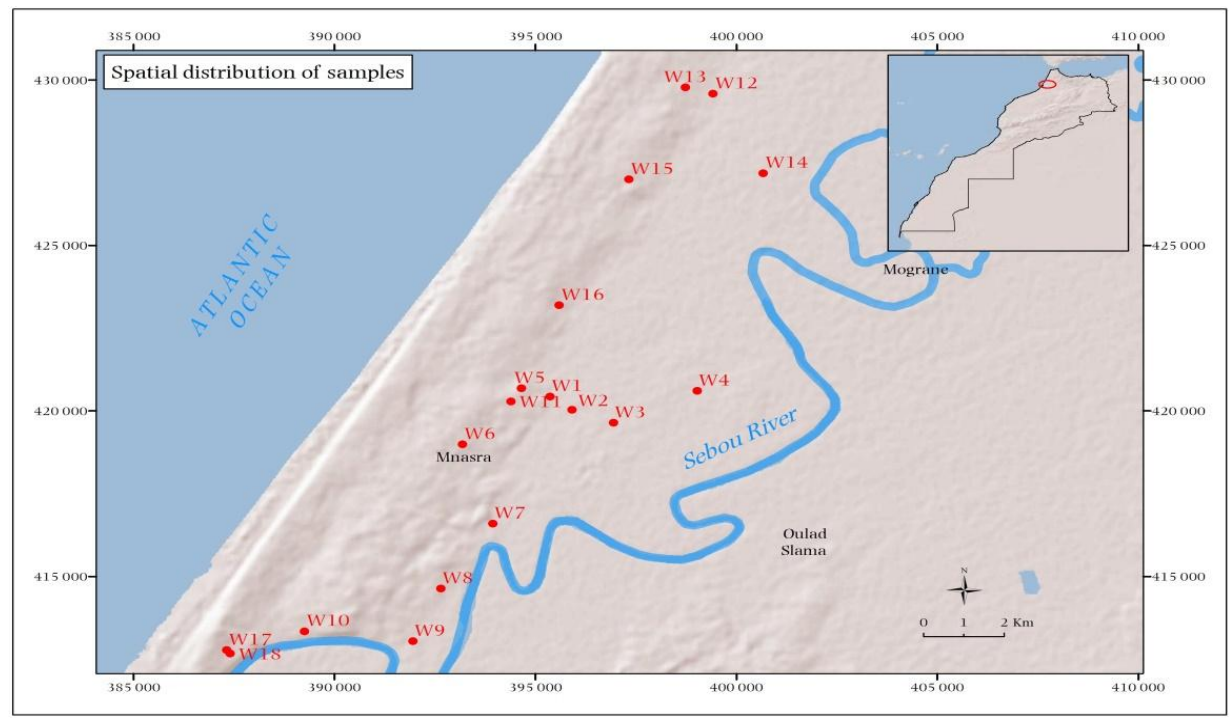

Figure 1 Map of M'nasra region, Morocco, area of sampling and the sampling points

Journal of Experimental Biology and Agricultural Sciences http://www.jebas.org 


\section{Materials and Methods}

\subsection{Study Area}

M'nasra zone is located in the Rabat-Salé-Kénitra Region, at $13 \mathrm{~km}$ from the city of Kenitra. The study area is dominated by sandy and clayey soils. The climate is the Mediterranean with annual precipitations ranging between 480 and $600 \mathrm{~mm}$, and the average temperature is $28.7^{\circ} \mathrm{C}$ in summer and $20.5^{\circ} \mathrm{C}$ in winter (ORMVAG, 2017: internal report). Water samples were collected from 18 wells (less than $50 \mathrm{~m}$ depth) installed in 18 sites located on the coastal zone of M'nasra in the Gharb region, Northwest of Morocco (Figure 1). The sample collection has been carried out in two seasons i.e. wet (winter) and Dry (summer) during 2017. Water samples were collected in 11 clean plastic bottles and stored in the freezer $\left(-10^{\circ} \mathrm{C}\right)$ until their analysis.

Soil samples were collected from the depth of $0-20 \mathrm{~cm}$ with the help of an auger. Then, these samples were air-dried, crushed, and sieved. Soil texture component (clay, silt, and sand) percentages were calculated using the Robinson pipette method (Pétard, 1993) at the laboratories of the National Institute of Agricultural Research (INRA), Rabat. The analysis of heavy metals $(\mathrm{Cd}, \mathrm{Cu}$, $\mathrm{Cr}, \mathrm{Mn}, \mathrm{Pb}, \mathrm{Ni}$, and $\mathrm{Zn}$ ) contents was carried out by using an Atomic Absorption Spectrophotometer (AAS) (Pinta, 1976). The dried sample is extracted with the help of a hydrochloric/nitric acid mixture by standing for $16 \mathrm{~h}$ at room temperature, followed by boiling under reflux for $2 \mathrm{~h}$. The extract is then clarified and made up to volume with nitric acid. The heavy metal content of the extract was determined by the International Organization for Standardization: ISO 11466/1995 protocol.

\subsection{Pollution indices}

\subsubsection{Contamination factor $(\mathrm{CF})$}

Pollution caused by each heavy metal was evaluated separately by using Contamination Factors $\left(\mathrm{C}_{\mathrm{f}}\right)$ as an individual pollution index (Eq.1).

$$
\mathrm{C}_{\mathrm{f}}=\mathrm{C} / \mathrm{C}_{\mathrm{r}}
$$

Where $C_{f}$ represents the Contamination Factor for a specific heavy metal, $\mathrm{C}$ is the determined concentration of the heavy metal, and $\mathrm{C}_{\mathrm{r}}$ represents the reference level.

According to Hakanson (1980), this $\mathrm{C}_{\mathrm{f}}$ index is a sedimentological risk index which used to describe the contamination of a given toxic substance in a lake or a sub-basin, and it was also successfully used for soil assessment (Qingjie et al.,2008; Likuku et al.,2013).

Further, As per Hakanson (1980), four classes have been used to describe the contamination factor, and these are: $\mathrm{C}_{\mathrm{f}}<1$ : "low contamination"; $1 \leq \mathrm{C}_{\mathrm{f}}<3$ : "moderate contamination"; $3 \leq \mathrm{C}_{\mathrm{f}}<6$ : "considerable contamination"; and $\mathrm{C}_{\mathrm{f}} \geq 6$ : "very high contamination". Since in Morocco no national thresholds considering the contamination of agricultural soils are established, the limits proposed by the World Health Organization (WHO) were used as a reference level for $\mathrm{C}_{\mathrm{f}}$.

\subsubsection{Nemerow pollution index}

The Nemerow pollution index (NI) is defined as (Nemerow, 1991):

$$
\mathrm{NI}=\sqrt{\frac{\left(\frac{1}{m} \sum_{i=1}^{m} C_{f}^{i}\right)^{2}+\left(C_{f \max }^{i}\right)^{2}}{2}}
$$

Where NI represents the Nemerow pollution index; $\mathrm{m}$ is the number of heavy metals taken into account; $\mathrm{C}_{\mathrm{f}}^{\mathrm{i}}$ is the individual pollution index calculated for the heavy metal $\mathrm{i} ; \mathrm{C}_{\mathrm{f} \max }^{\mathrm{i}}$ is the maximum value of individual indices $\mathrm{C}_{\mathrm{f}}^{\mathrm{i}}$.

The Nemerow pollution index is, probably, the most used multielement pollution index and frequently used in previously conducted researches in China (Ma et al., 2015), India (Giri, et al., 2017), Algeria (Ramdani et al., 2018), and Poland (Wieczorek \& Baran, 2021). Giri et al. (2017) distinguished five NI categories and these are $\mathrm{NI}<0.7$ : "safety domain"; $0.7 \leq \mathrm{NI}<1.0$ : "precaution domain"; $1.0 \leq \mathrm{NI}<2.0$ : "slightly polluted domain"; $2.0 \leq \mathrm{NI}<3.0$ : "moderately polluted domain"; and NI>3.0: "seriously polluted domain".

\subsection{Statistical analysis}

Descriptive statistics, paired t-test and hierarchical cluster analysis (HCA) were conducted using the IBM SPSS Statistics statistical software, version 25. For comparison analysis limits from World Health Organization (WHO) were used because in Morocco there are no national standards or threshold established for metal concentrations. Raw values were standardized before HCA. For the latter, the Ward method with squared Euclidean distance was applied to the variables to assess the similarity degree between them (Field, 2006). The distribution maps were generated in the ArcMap application from ArcGIS 10 software using the Inverse Distance Weighting (IDW) spatial interpolation approach (El Khodrani et al., 2019; Wojciech, 2020; Ghorbani et al., 2020).

\section{Results and Discussion}

\subsection{Seasonal variation}

Range and mean values of the concentrations of heavy metals determined in topsoil and groundwater are summarized in Table 1. The percent exceeding was calculated for all elements that have percentage values exceeding the WHO/CCME limits (CCME, 2007). Results of the study suggested that for groundwater heavy 
Table 1 Range, average, and percentage of samples exceeding the WHO/CCME thresholds for the heavy metal concentrations from groundwater and topsoil in M'nasra zone, Morocco

\begin{tabular}{|c|c|c|c|c|c|}
\hline \multirow{2}{*}{\multicolumn{2}{|c|}{$\mathrm{n}^{\mathrm{a}}=18$}} & \multicolumn{2}{|c|}{ Groundwater (mg/l) } & \multicolumn{2}{|c|}{ Soil (mg/kg) } \\
\hline & & Winter & Summer & Winter & Summer \\
\hline \multirow{3}{*}{$\mathrm{Cd}$} & Range & $0.000-0.004$ & $0.001-0.005$ & $0.00-1.10$ & $0.40-1.60$ \\
\hline & Mean & 0.002 & 0.002 & 0.38 & 0.97 \\
\hline & \%exceeding $^{\mathrm{b}}$ & $16.7 \%$ & $27.8 \%$ & $0.0 \%$ & $16.7 \%$ \\
\hline \multirow{3}{*}{$\mathrm{Cu}$} & Range & $0.000-0.040$ & $0.000-0.010$ & $9-357$ & $21-131$ \\
\hline & Mean & 0.016 & 0.001 & 54.67 & 59.85 \\
\hline & \%exceeding $^{\mathrm{b}}$ & $0 \%$ & $0 \%$ & $11.1 \%$ & $11.1 \%$ \\
\hline \multirow{3}{*}{$\mathrm{Cr}$} & Range & $0.002-0.047$ & $0.013-0.058$ & $50-2993$ & $51-222$ \\
\hline & Mean & 0.025 & 0.037 & 466.50 & 93.23 \\
\hline & \%exceeding $^{b}$ & $0 \%$ & $11.1 \%$ & $72.2 \%$ & $66.7 \%$ \\
\hline \multirow{3}{*}{$\mathrm{Mn}$} & Range & $0.000-0.010$ & $0.000-0.010$ & $310-1030$ & $450-1530$ \\
\hline & Mean & 0.001 & 0.004 & 585.28 & 859.14 \\
\hline & \%exceeding $^{\mathrm{b}}$ & $0 \%$ & $0 \%$ & $0 \%$ & $0 \%$ \\
\hline \multirow{3}{*}{$\mathrm{Pb}$} & Range & $0.000-0.060$ & $0.000-0.050$ & $0-50$ & $2-146$ \\
\hline & Mean & 0.011 & 0.019 & 16.5 & 32.26 \\
\hline & \%exceeding & $22.2 \%$ & $55.6 \%$ & $0 \%$ & $5.6 \%$ \\
\hline \multirow{3}{*}{$\mathrm{Ni}$} & Range & $0.010-0.090$ & $0.030-0.070$ & $22-1489$ & $35-813$ \\
\hline & Mean & 0.049 & 0.048 & 199.08 & 135.22 \\
\hline & $\%_{\text {exceeding }}{ }^{b}$ & $77.8 \%$ & $100 \%$ & $83.3 \%$ & $77.8 \%$ \\
\hline \multirow{3}{*}{$\mathrm{Zn}$} & Range & $0.000-0.004$ & $0.000-0.010$ & $0-2800$ & $27-290$ \\
\hline & Mean & 0.012 & 0.002 & 1615.28 & 131.97 \\
\hline & \%exceeding & $0 \%$ & $0 \%$ & $94.5 \%$ & $11.1 \%$ \\
\hline
\end{tabular}

$\mathrm{n}^{\mathrm{a}}=$ number of sampling locations per season; \% exceeding ${ }^{\mathrm{b}}=$ percentage of locations where WHO/CCME thresholds are exceeded

metal values and percentages increased from wet to dry seasons and the highest values were reported from the water sample collected in the dry season. While in the case of soil samples, the value and percentage of all heavy metals except for $\mathrm{Cd}$ and $\mathrm{Pb}$ were found to decrease in dry seasons. Also, the values over the thresholds were registered for $\mathrm{Cd}, \mathrm{Pb}, \mathrm{Ni}$ (both seasons), and $\mathrm{Cr}$ (only dry season) in groundwater, while there were registered for $\mathrm{Cu}, \mathrm{Cr}, \mathrm{Ni}, \mathrm{Zn}$ (both seasons), $\mathrm{Cd}$, and $\mathrm{Pb}$ (only dry season) for soil.

The order of magnitude of the heavy metal concentrations in the soil followed similar trends to that in the irrigation water, except for $\mathrm{Cu}$ and $\mathrm{Zn}$. Namely, the Ni concentration was highest, and the concentrations of $\mathrm{Cd}$ and $\mathrm{Pb}$ were low, suggesting that the soil contamination was caused by the contaminated irrigation water. Concerning the order of the concentrations, the soil $\mathrm{Cu}$ and $\mathrm{Zn}$ concentrations were different from the concentrations in irrigation water. Therefore, some factors might be differentially affecting the contamination levels.

\subsection{Heavy Metal Concentrations of Irrigation Water and Seasonal Differences}

The mean heavy metal concentrations $(\mathrm{mg} / \mathrm{L})$ of irrigation water for both wet and dry seasons are given in Table 2, with $\mathrm{CV}$ values shown in parentheses. Among the studied heavy metals, $\mathrm{Ni}$ had the highest and $\mathrm{Cu}$ had the lowest concentrations. The order of the heavy metal concentration (according to mean values of all areas) was reported as $\mathrm{Ni}>\mathrm{Cr}$ $>\mathrm{Cu}>\mathrm{Zn}>\mathrm{Pb}>\mathrm{Cd}$ in the wet season while it was reported as $\mathrm{Ni}>\mathrm{Cr}>\mathrm{Cu}>\mathrm{Zn}>\mathrm{Cd}>\mathrm{Pb}$ in the dry season. In order of heavy metals concentration, there is a permutation between $\mathrm{Cd}$ and $\mathrm{Pb}$ in both seasons. The concentrations of $\mathrm{Cr}, \mathrm{Cu}$ and $\mathrm{Zn}$ were significantly different between the two seasons according to paired $\mathrm{t}$-test $\left(\mathrm{t}_{\mathrm{Cr}}=2.85, \mathrm{t}_{\mathrm{Cu}}=-4.91, \mathrm{t}_{\mathrm{Zn}}=-4.12, \mathrm{p}<0.05\right)$. These differences are illustrated in Figure 2, even though we have median values instead of mean values that were compared in the paired t-test. 
Table 2 Mean (mg/L) and coefficient of variation (\%, in parentheses) of heavy metal concentration of irrigation water in wet and dry seasons

\begin{tabular}{|cccccccc|}
\hline Seasons & $\mathrm{Cd}$ & $\mathrm{Cu}$ & $\mathrm{Cr}$ & $\mathrm{Pb}$ & \multicolumn{2}{c}{$\mathrm{Ni}$} & $\mathrm{Zn}$ \\
\hline \multirow{2}{*}{ Wet $(\mathrm{N}=18)$} & 0.0019 & 0.0161 & 0.0248 & 0.0111 & 0.0494 & 0.0117 \\
& $(65.1 \%)$ & $(74.2 \%)$ & $(56.8 \%)$ & $(171.6 \%)$ & $(51.7 \%)$ & $(79.1 \%)$ \\
\hline \multirow{2}{*}{ Dry (N=18) } & 0.0017 & 0.0194 & 0.0375 & 0.0011 & 0.0478 & 0.0027 \\
& $(84.2 \%)$ & $(16.6 \%)$ & $(31.6 \%)$ & $(1363.6 \%)$ & $(26.4 \%)$ & $(141.0 \%)$ \\
\hline Permissible level $^{\mathrm{a}}$ & 0.003 & 2 & 0.05 & 0.01 & 0.02 & 3 \\
\hline
\end{tabular}

N: number of samples; ${ }^{a}$ World Health Organization (WHO) standard (Martin \& Griswold, 2009)

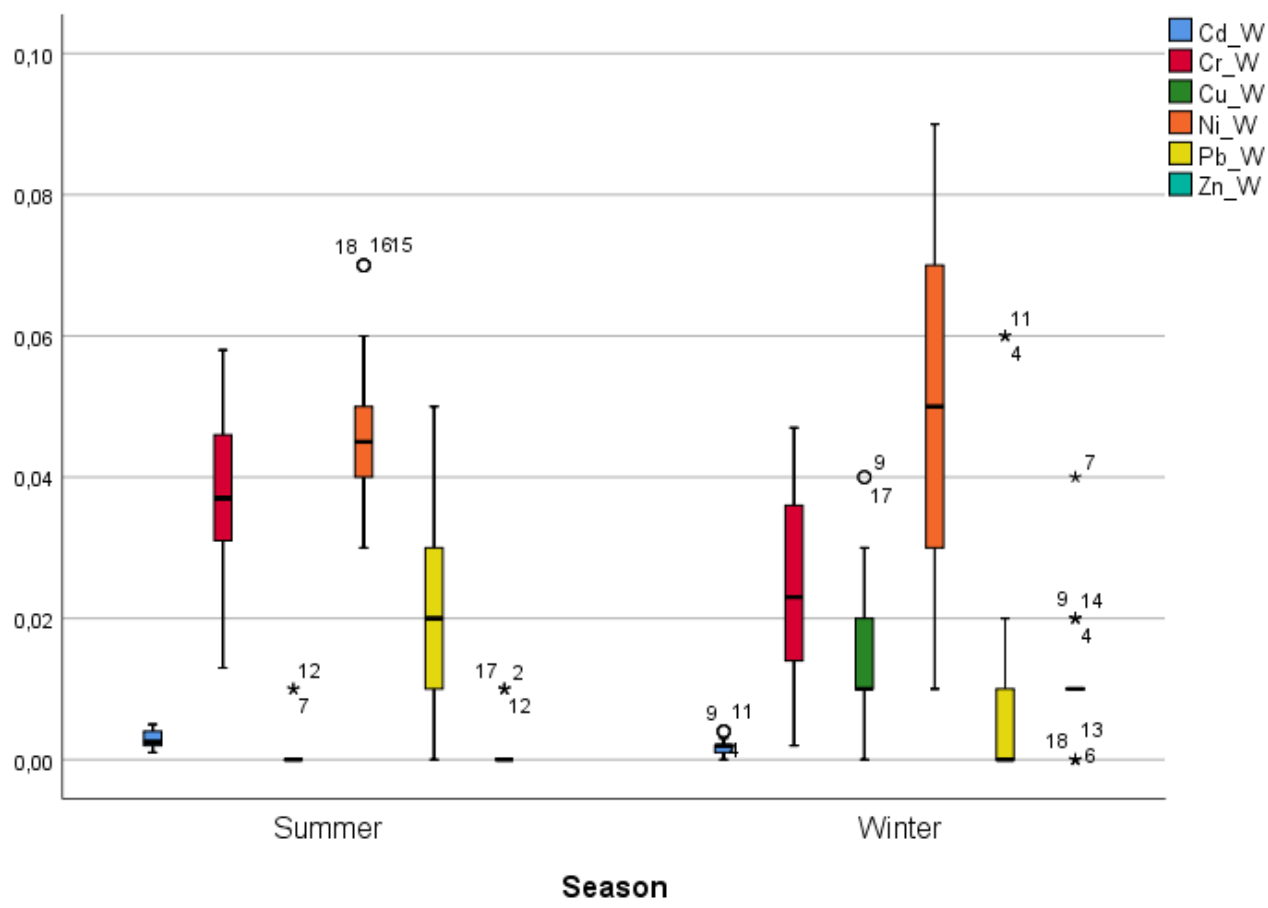

Figure 2 Box and whisker plots for groundwater heavy metals in dry and wet seasons

The CV of heavy metal concentrations mostly ranged from 51.7 to $171.6 \%$ in the wet season, and from 16.6 to $1363.6 \%$ in the dry season (Table 2). Based on the paired t-test, there was no significant difference between the two seasons for any heavy metal. The heavy metal concentrations exceeded the World Health Organization (Martin \& Griswold, 2009) permissible levels case of $\mathrm{Pb}$ and $\mathrm{Ni}$ (in both seasons) (Table 2). Therefore, the water has been identified to be inappropriate to use for irrigation purposes.

\subsection{Heavy Metal Concentrations of Soil and Seasonal Differences}

Mean values and CV (\%, in parentheses) of soil heavy metal concentration $(\mathrm{mg} / \mathrm{kg})$ for both seasons are summarized in Table 3 . Among the tested heavy metals, $\mathrm{Zn}$ had the highest and $\mathrm{Cd}$ the lowest concentration. The order of concentration (according to mean values of all zones) was $\mathrm{Zn}>\mathrm{Cr}>\mathrm{Ni}>\mathrm{Cu}>\mathrm{Pb}>\mathrm{Cd}$ in wet season and $\mathrm{Ni}>\mathrm{Zn}>\mathrm{Cr}>\mathrm{Cu}>\mathrm{Pb}>\mathrm{Cd}$ in the dry season. In this order, there is a permutation between $\mathrm{Zn}, \mathrm{Cr}$, and $\mathrm{Ni}$ in both seasons. As mentioned in figure 3 , the $\mathrm{Cd}$ and $\mathrm{Zn}$ concentrations were significantly different between the two seasons based on the paired t-test $\left(\mathrm{t}_{\mathrm{Cd}}=4.25, \mathrm{t}_{\mathrm{Zn}}=-9.53, \mathrm{p}<0.05\right)$.

For soil, $\mathrm{Zn}, \mathrm{Cr}$, and Ni mean values differed significantly between the two seasons while for the groundwater, $\mathrm{Cu}, \mathrm{Zn}$, and $\mathrm{Pb}$ mean values were different between the two seasons, which may be due to the difference between absorption ability of heavy metals in soil which is somewhat different among species and is affecting the concentration.

Heavy metal concentrations were highly variable as their CV ranged from 40.13 to $186.52 \%$ in the wet season and from 44.73 to $129.47 \%$ in the dry season. The mean concentration in the dry season was not significantly different from that the wet season (paired t-test). The $\mathrm{Ni}$ and $\mathrm{Cr}$ concentrations were greater than the permissible CCEM level (CCEM, 2007) in both seasons, and $\mathrm{Zn}$ in the wet season (Table 3). Therefore, the soil has been considered to be inappropriate for planting purposes. 
Table 3 Mean values of soil heavy metal concentration $(\mathrm{mg} / \mathrm{Kg})$ and coefficient of variation $(\%$, in parentheses) in wet and dry seasons

\begin{tabular}{|c|c|c|c|c|c|c|}
\hline Seasons & $\mathrm{Cd}$ & $\mathrm{Cu}$ & $\mathrm{Cr}$ & $\mathrm{Pb}$ & $\mathrm{Ni}$ & $\mathrm{Zn}$ \\
\hline Wet $(\mathrm{N}=18)$ & $\begin{array}{l}0.3778 \\
(84.96)\end{array}$ & $\begin{array}{l}54.6667 \\
(147.78)\end{array}$ & $\begin{array}{r}466.5028 \\
(162.70)\end{array}$ & $\begin{array}{c}16.5000 \\
(76.70)\end{array}$ & $\begin{array}{r}199.0833 \\
(186.52)\end{array}$ & $\begin{array}{c}1615.2778 \\
(40.13)\end{array}$ \\
\hline Dry $(\mathrm{N}=18)$ & $\begin{array}{l}0.9717 \\
(44.73)\end{array}$ & $\begin{array}{l}59.8517 \\
(49.19)\end{array}$ & $\begin{array}{c}93.2094 \\
(44.73)\end{array}$ & $\begin{array}{l}32.2594 \\
(102.46)\end{array}$ & $\begin{array}{l}135.2161 \\
(129.47)\end{array}$ & $\begin{array}{c}131.9722 \\
(46.89)\end{array}$ \\
\hline Permissible level ${ }^{\mathrm{a}}$ & 1.4 & 100 & 64 & 70 & 50 & 200 \\
\hline
\end{tabular}

$\mathrm{N}$ : number of samples; ${ }^{\mathrm{C}} \mathrm{CCME}$ (Canadian Council of Ministers of Environmental).

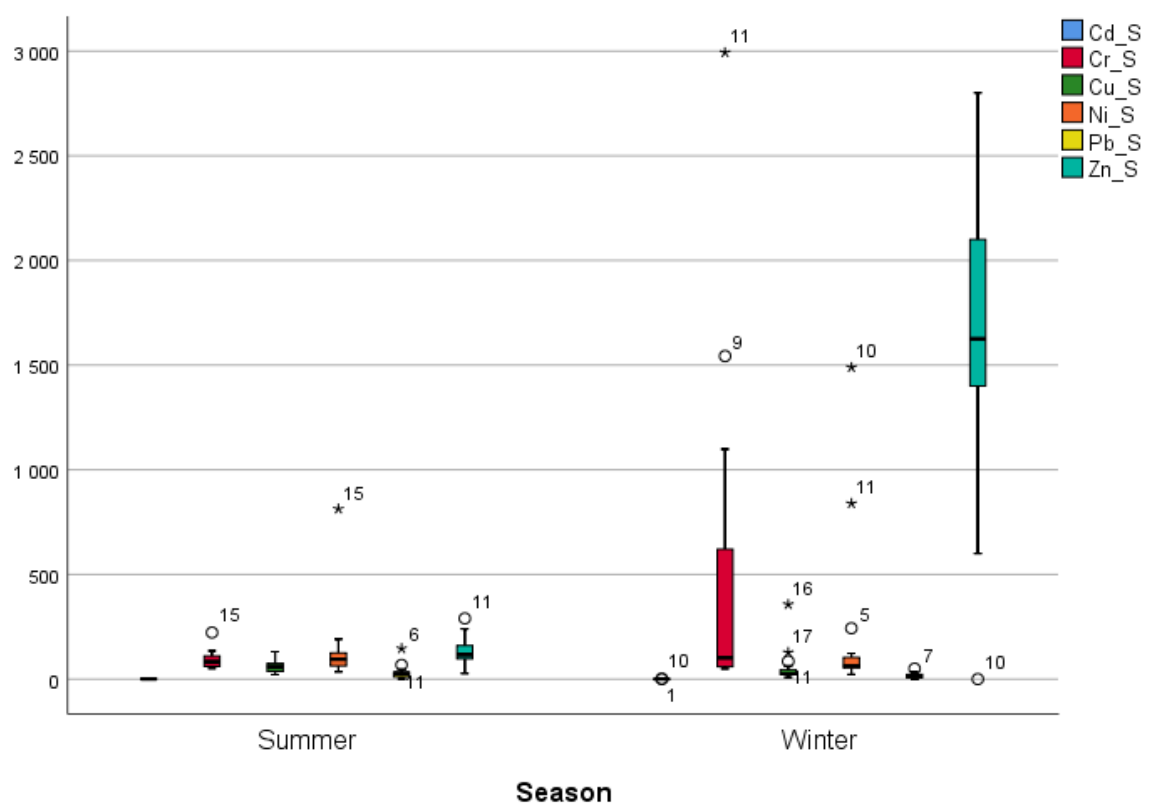

Figure 3 Box and whisker plots with the soil heavy metals concentrations in dry and wet seasons

\subsection{Vertical transfer}

The data in table 1 are highlighting a possible vertical transfer of pollutants from topsoil to groundwater, favored by the large quantities of rain during the wet season. Vertical transfer of heavy metals from topsoil to groundwater is depending on the soil composition. Soils with high content of clay and slit favored the accumulation of heavy metals, while, the water from the sandy soil easily passed during the rainfalls, thus this soil favoring the transport of heavy metals to the deeper and sometimes these heavy metals reached to the groundwater (Rajmohan et al., 2014).

The dry season dendrogram (Figure 4) was confirmed by the results of the Kouchou et al. (2020) and Lencha et al. (2021). Among the tested heavy metals, $\mathrm{Cr}$ and $\mathrm{Ni}$ showed the shortest cluster distance (less than $<5$ ) which suggested that the soil correlating with high silt ( $\mathrm{Z}$ silt) concentrations. The results correlated with the increase of the values of $\mathrm{Ni}$ and $\mathrm{Cr}$ than the WHO limits in groundwater highlight the possibility of vertical transfer of these two metals from upper soil layers. The contamination of heavy metals in soil is higher in the wet season, and this might be due to the excess use of pesticides and fertilizers in crop production season (Minhaz et al., 2018).

The distribution map for Ni in soil shows a location of maximum values in the North-East part of the M'nasra zone (Figure 5a). The pattern of $\mathrm{Ni}$ concentrations distribution in groundwater (Figure 5 b) follows the slope of the terrain from the high accumulation zone in the North-East to the lower grounds near the Sebou River. The increased value of $\mathrm{Ni}$ in the soil during winter can be explained by the addition of contaminants during farming activities and the chemical behavior of $\mathrm{Ni}$ in water. (Table1).

The distribution map for $\mathrm{Cr}$ in soil showed the maximum values of $\mathrm{Cr}$ from the South-East part of the M'nasra zone (Figure 6a), while in the case of groundwater, maximum values of $\mathrm{Cr}$ was reported from the South and northwest parts of the study zone (Figure 6b). The increase of values of $\mathrm{Cr}$ in soil (Table 1) during the wet season could be explained by the addition of contaminants during the season-specific activities (Andrea et al., 2019). To determine the sources of contamination, further extensions of this study are needed for monitoring the quality of agricultural soil and well water. 



Figure 4 HCA Dendograms using squared Euclidean distance and Ward linkage for soil composition and heavy metal concentrations in M'nasra zone, Morocco during (a) Dry season and b) wet season.

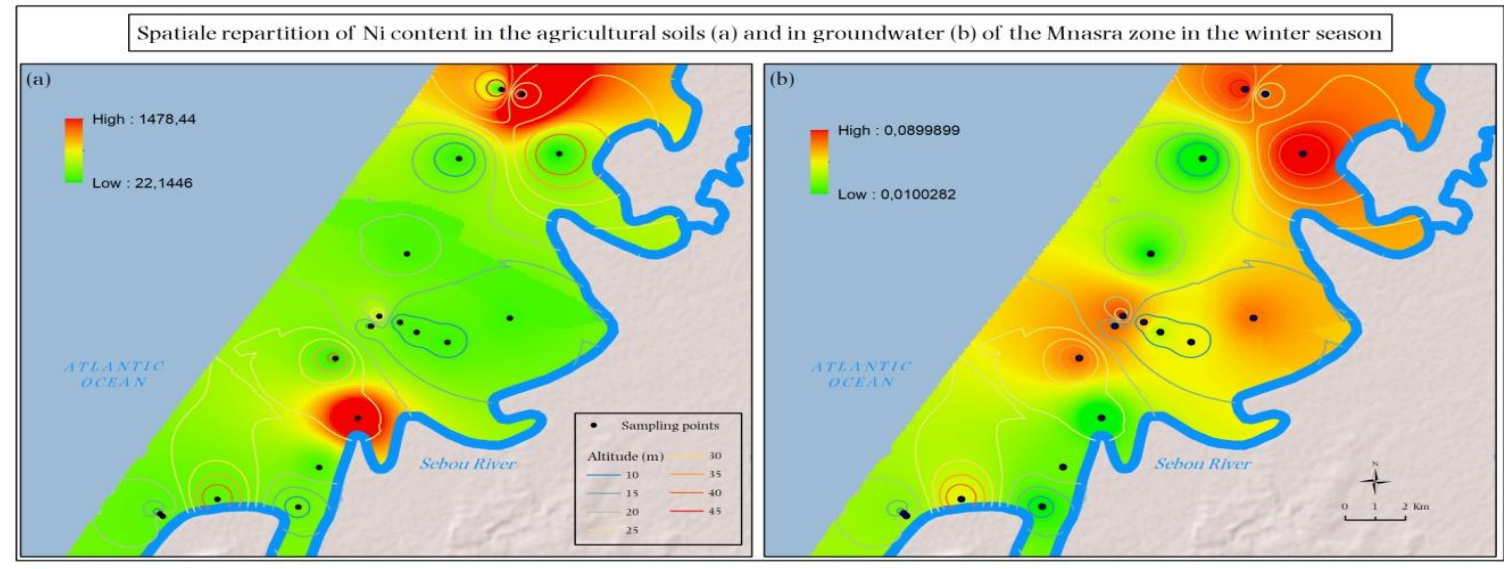

Figure 5 Distribution maps of Ni concentrations determined from topsoil (a) and groundwater (b) during winter (wet season) in M’nasra zone, Morocco

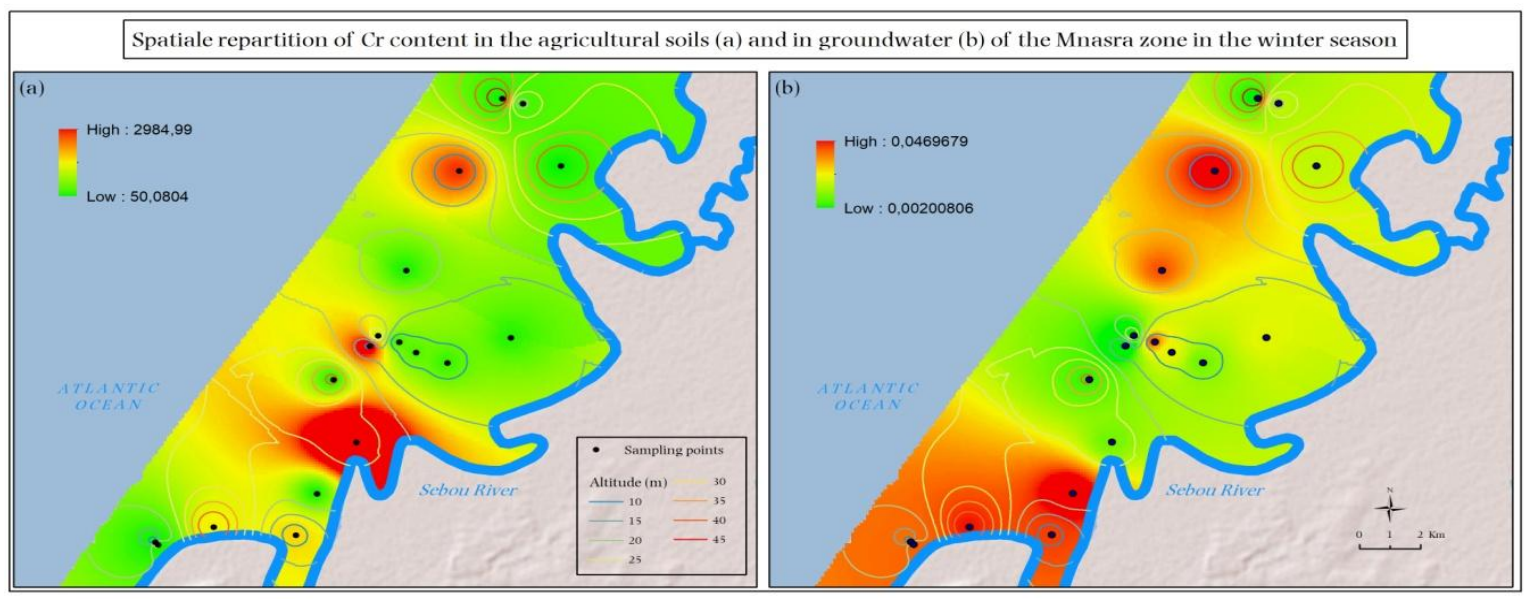

Figure 6 Distribution maps of $\mathrm{Cr}$ concentrations determined from topsoil (a) and groundwater (b) during winter (wet season) in M'nasra zone, Morocco

Journal of Experimental Biology and Agricultural Sciences http://www.jebas.org 


\subsection{Degree of soil contamination}

Based on the soil contamination factor, the "considerable contamination" category was reported, among the tested samples, $22.23 \%$ of $\mathrm{Cr}$ samples and $44.5 \%$ of $\mathrm{Ni}$ samples were reported in the wet season, and it was found similar to the dry season $\mathrm{Ni}$ (22.2\% of samples), whereas the "very high contamination" was found for $\mathrm{Zn}$ (100\% of samples), $\mathrm{Cr}$ (77.8\% of samples) and $\mathrm{Ni}$ $(33.3 \%)$ all in the wet season.

Considering the total pollution based on the Nemerow index, the majority of the locations can be classified in the "seriously polluted domain" ( $50 \%$ of samples in wet and $16.7 \%$ in dry), while $50 \%$ of samples in both dry and wet seasons were found in the "safety domain" category. In contrast, only $16.7 \%$ of samples in summer were found for each of "precaution domain" and "slightly polluted domain" categories.

For groundwater, $\mathrm{Cu}, \mathrm{Cr}, \mathrm{Cd}$, and $\mathrm{Zn}$ have values that come under the "low contamination" category in both seasons, while $100 \%$ of $\mathrm{Ni}$ samples and $77.8 \%$ of $\mathrm{Pb}$ samples can be classified as "moderate contamination" in the dry season. In the wet season, the percentages of samples in higher contaminated categories were decreased and it was reported $33.3 \%$ for $\mathrm{Ni}, 44.5 \%$ for $\mathrm{Pb}$.

Considering the total pollution based on Nemerow index, $62.5 \%$ of samples in dry and $75 \%$ in wet can be kept in the "safety domain", while $12.5 \%$ of samples of the dry season comes in "precaution domain", and $12.5 \%$ of samples of the wet season comes in "slightly polluted domain". In the "moderately polluted domain" $25 \%$ of dry and $12.5 \%$ of wet season samples were kept.

\section{Conclusion}

Locations, where the concentrations of heavy metals in groundwater and soil are exceeding the WHO/CCME threshold limits, were identified in the current study. The degree of contamination calculated using pollution indices is rising to "seriously polluted domain" for soil and "moderately polluted domain" for groundwater in both seasons. In the wet season, heavy metal concentrations in irrigation water, and soil were lower than in the dry season. Further, during the study seasonal variation was identified, and concentrations, as well as the percentage of heavy metals contamination exceeding the WHO limits, are decreasing in groundwater from dry to wet season while this is increasing in soil (except $\mathrm{Cd}$ and $\mathrm{Pb}$ )

Results of Hierarchical Cluster Analysis showed an association between the heavy metals concentrations and soil texture (clay, silt, and sand components in soil) and soil texture and heavy metal concentrations in groundwater in both seasons, this association highlighting the possibility of vertical transfer of pollutants from topsoil to groundwater. Further, in the case of $\mathrm{Ni}$ and $\mathrm{Cr}$, the vertical transfer is confirmed by the correlation between variables and by the spatial pattern of concentrations distribution in groundwater. This study can be considered as a baseline for the seasonal variation of heavy metal pollution of groundwater and soil in North-West Morocco.

\section{Acknowledgments}

We want to thank all the people who have helped us in the field and laboratory throughout this work.

\section{Disclosure statement}

No potential conflict of interest was reported by the author(s).

\section{References}

Aaseth J, Norseth T (1986) Copper, in Handbook on the Toxicology of Metals, (2nd ed.). In: Friberg L, Nordberg GF, Vouk VB, Elsevier, Amsterdam, 233-254.

Agca N, Özdel E (2014) Assessment of spatial distribution and possible sources of heavy metals in the soils of Sariseki-Dörtyol District in Hatay Province (Turkey). Environmental Earth Sciences 71: 1033-1047.

Andrea MME, Carolina TEA, Joséc CBT, Luis MNJ, Carlos GML (2019) Evaluation of contaminants in agricultural soils in an Irrigation District in Colombia. Heliyon 5: E02217.DOI: https://doi.org/10.1016/j.heliyon.2019.e02217.

Banerjee S, Kumar A, Kumar Maiti S, Chowdhury A (2016) Seasonal variation in heavy metal contaminations in water and sediments of Jamshedpur stretch of Subarnarekha River, India. Environmental Earth Sciences 75:265.

Ben Salem Z, Capelli N , Laffray X, Elise G, Ayadi H , Aleya L (2014) Seasonal variation of heavy metals in water, sediment and roach tissues in a landfill draining system pond (Etueffont, France). Ecological Engineering 69:25-37.

Canadian Council of Ministers of Evironmental (2007) Canadian soil quality guidelines for the protection of environmental and human health. Retrieve from https://ccme.ca/en/currentactivities/canadian-environmental-quality-guidelines.

De Bie P, Van de Sluis B, Klomp L, Wijmenga C (2005) The Many Faces of the Copper Metabolism Protein MURR1/COMMD1. Journal of Heredity 96:803-811.

El Khodrani N, Omrania S, Zouahri A, Douaik A, Iaaich H, Yahyaoui A, Fekhaoui M (2019) Spatial Distribution and Mapping of Heavy Metals in Agricultural Soils of the Sfafaa region (Gharb, Morocco). Materials Today: Proceedings 13:832-840. 
Field A (2006) Discovering statistics using SPSS. SAGE Publications.

Ghorbani S, Mohammadi A, Teiri H, Hajizadeh Y (2020) Spatiotemporal variations of asbestos fibers levels in ambient air of a densely populated and industrialized city of Iran. International Journal of Environmental Analytical Chemistry. DOI: $10.1080 / 03067319.2020 .1751144$

Giri S, Singh AK, Mahato MK (2017) Metal contamination of agricultural soils in the copper mining areas of Singhbhum shear zone in India. Journal of Earth System Science 126: 49. DOI 10.1007/s12040-017-0833-z.

Hakanson L (1980) An ecological risk index for aquatic pollution control. A sedimentological Approach. Water Research 14: 9751001.

Hellström L, Jarup L, Persson B, Axelson O (2004) Using environmental concentrations of cadmium and lead to assess human exposure and dose. Journal of Exposure Analysis and Environmental Epidemiology 14:416-423.

International Organization for Standardization (1995): ISO $11466 / 1995$, Soil Quality - Extraction of trace elements soluble in aqua regia, Geneva, Switzerland.

Islam MS, Ahmed MK, Habibullah-Al-Mamun M, Islam SMA (2017) Sources and Ecological Risks of Heavy Metals in Soils Under Different Land Uses in Bangladesh. Pedosphere 29:665675 .

Järup L, Akesson A (2009) Current status of cadmium as an environmental health problem. Toxicology and Applied Pharmacology 238: 201-208.

Kouchou A, El Ghachtouli N, Duplay J, Ghazi M, Elsass F, Thoisy JC, Bellarbi M, Ijjaali M, Rais N (2020) Evaluation of the environmental and human health risk related to metallic contamination in agricultural soils in the Mediterranean semi-arid area (Saiss plain, Morocco). Environmental Earth Sciences 79:131.

Lencha SM, Ulsido MD, Muluneh A (2021) Evaluation of Seasonal and Spatial Variations in Water Quality and Identification of Potential Sources of Pollution Using Multivariate Statistical Techniques for Lake Hawassa Watershed, Ethiopia. Applied Sciences 19: 8991; https://doi.org/10.3390/app11198991.

Likuku AS, Mmolawa KB, Gaboutloeloe GK (2013) Assessment of Heavy Metal Enrichment and Degree of Contamination around the Copper-Nickel Mine in the SelebiPhikwe Region, Eastern Botswana. Environment and Ecology Research 1:32-40.
Ma L, Sun J, Yang Z, Wang L(2015) Heavy metal contamination of agricultural soils affected by mining activities around the Ganxi River in Chenzhou, Southern China. Environmental Monitoring and Assessment 187: 731.

Martin S, Griswold W (2009) Human Health Effects of Heavy Metals. Environmental Science and Technology Briefs for Citizens 15:1-6.

Minhaz M, Masaru M, Kiyoshi K (2018) Heavy Metal Contamination of Irrigation Water, Soil, and Vegetables in a Multi-industry District of Bangladesh. International Journal of Environmental Research 12: 531-542.

Minhaz A, Masaru M, Akinori O, Nguyen Van T, Kiyoshi K (2019) Heavy Metal Contamination of Irrigation Water, Soil, and Vegetables and the Difference between Dry and Wet Seasons Near a Multi-Industry Zone in Bangladesh. Water 11: 583.

Navarro Silvera SA, Rohan TE (2007) Trace elements and cancer risk: a review of the epidemiologic evidence. Cancer Causes Control 18:7-27.

Nemerow NL (1991) Stream, lake, estuary, and ocean pollution, 2nd ed. New York, USA: Wiley.

Nshimiyimana FX, Faciu ME, El Abidi A, El Blidi S, Fekhaoui M, LoredanaIfrim I, Soulaymani A, Lazar G (2014) Analysis of seasonal variation on degree of contamination with heavy metals in Aarjate village, Morocco: An index approach. Chemistry \& Chemical Engineering, Biotechnology, Food Industry 15:337 344.

Nyantakyi AJ, Akoto O, Fei-Baffoe B (2019) Seasonal variations in heavy metals in water and sediment samples from River Tano in the Bono, Bono East, and Ahafo Regions, Ghana. Environmental Monitoring and Assessment 191: 570.

Pétard J (1993) Les méthodes d'analyse. Analyse de sols. Nouméa, nouvelle Calédonie: ORSTOM, Pp192.

Pinta M(1976) «Spectrométrie d'absorption atomique »: application à l'analyse chimique, Pp 470.

Qingjie G, Jun D, Yunchuan X, Qingfei W, Liqiang Y (2008) Calculating Pollution Indices by Heavy Metals in Ecological Geochemistry Assessment and a Case Study in Parks of Beijing. Journal of China University of Geosciences 19:230-241.

Rajmohan N, Prathapar SA, Jayaprakash M, Nagarajan R (2014) Vertical distribution of heavy metals in soil profile in a seasonally waterlogging agriculture field in Eastern Ganges Basin. Environmental Monitoring and Assessment 186: 5411-5427. 
Ramdani S, Amar A, Belhsaien K, El Hajjaji S, Ghalem S, Zouahri A, Douaik A (2018) Assessment of Heavy Metal Pollution and Ecological Risk of Roadside Soils in Tlemcen (Algeria) Using Flame-Atomic Absorption Spectrometry. Analytical Letters 51: 2468-2487.

Sophia S, John Milton MC, Prakash M (2017) Analysis and Seasonal Variation of Heavy Metals in Water and Sediment from Adyar Estuary. Environmental Risk Assessment and Remediation 1:23-28.

Yan X, Liu M, Zhong J, Guo J, Wu W (2018) How Human Activities Affect Heavy Metal Contamination of Soil and Sediment in a Long-Term Reclaimed Area of the Liaohe River Delta, North China. Sustainability 10:338.

UN-Water SDG 6 Synthesis Report (2018) UN-Water SDG 6 Synthesis Report on Water and Sanitation Nations, U, New York, p. 2018
WHO/UNICEF (2017) Progress in Drinking Water and Sanitation: Update and SDG BaselineWorld Health Organization (WHO) and United Nations Children's Fund (UNICEF), Geneva, Switzerland and New York City, NY, USA.

Wieczorek J, Baran A (2021) Pollution indices and biotests as useful tools for the evaluation of the degree of soil contamination by trace elements. Journal of Soils and Sediments. https://doi.org/10.1007/s11368-021-03091-x.

Wojciech M (2020) Inverse distance weighting method optimization in the process of digital terrain model creation based on data collected from a multi beam echo-sounder. Applied Geomatics12:397-407.

Wuana RA, Okieimen FE (2011) Heavy Metals in Contaminated Soils: A Review of Sources, Chemistry, Risks and Best Available Strategies for Remediation. International Scholarly Research Network-ISRN Ecology, ID 402647, 1-20. https://doi.org/10.5402/2011/402647. 